\title{
Anthós
}

\section{The Impact of COVID-19 on International Students at Portland State University}

Aakanksha Santosh Rane

Portland State University

Follow this and additional works at: https://pdxscholar.library.pdx.edu/anthos

Part of the Education Commons, and the Social and Behavioral Sciences Commons Let us know how access to this document benefits you.

\section{Recommended Citation}

Rane, Aakanksha Santosh (2021) "The Impact of COVID-19 on International Students at Portland State University," Anthós: Vol. 10: Iss. 1, Article 13.

https://doi.org/10.15760/anthos.2021.10.1.13

This open access Article is distributed under the terms of the Creative Commons Attribution-NonCommercialShareAlike 4.0 International License (CC BY-NC-SA 4.0). All documents in PDXScholar should meet accessibility standards. If we can make this document more accessible to you, contact our team. 


\section{The Impact of COVID-19 on International Students at Portland State University}

Aakanksha Santosh Rane

\section{Background Information}

In the United States, people who reside in the country in order to pursue higher education on a F1 or J1 visa are considered international students. According to data collected by the U.S. Department of Commerce, international students contributed $\$ 4.7$ billion to the U.S. economy in 2018, which was a 5.5\% increase from previous years (Reuters, 2020). In addition to this, data collected by the National Association of International Educators (NAFSA), an international education advocacy group suggests "about 460,000 jobs in the United States during the 2018-2019 academic year were supported by international students." (Reuters, 2020).

Most full-time international students are on an F1 or J1 visa which allows them to legally reside in the country as they attend university. In order to qualify for an F1 visa student must be enrolled in an "academic" educational program as a full-time student. The student must also prove that they have sufficient funds to support themselves during their duration of stay in the United States (U.S.

Citizenship and Immigration Services. (2020, May 01)). International students on the F1 visa tend to also face a lot of barriers that threaten their ability to live in the United States after they complete pursuing their higher education. Firstly, students can only apply for an F1 visa after they get accepted as a student by an academic institution in the United States. In addition to this, international students are not allowed to work off campus legally without special permission from the university and U.S. government (Galstyan Law, n.d.). Despite all these limitations, gaining an F1 is the easiest way for an international student to pursue higher education in the United States.

Portland State University (PSU) is currently the home for more than 2,000 international students from nearly 100 different countries (Portland State University, n.d.). In 2018, international students represented $7.3 \%$ of the overall student body at PSU (Portland State University, n.d.). The undergraduate program at PSU reports having about 1,280 international students (Portland State University, n.d.). Portland State University also reports having over $10 \%$ of their graduate students from countries outside of the U.S. (Portland State University (n.d.)). Many of these international students are in the process of starting a new chapter in their lives as they move out of their family homes to a new country.

The COVID-19 pandemic and the social distancing regulations in place resulted in universities closing down campuses in the United States. Over 1,100 colleges and universities, in the United States, had cancelled all in-person classes and shifted to a virtual or remote learning by mid-March, 2020. This also led to

\footnotetext{
${ }^{1}$ This article, which was based on a class project rather than a research study, was not reviewed by
} the PSU IRB. 
many colleges and high school graduations being conducted remotely, being cancelled, or being postponed (Smalley, 2020). In addition to classes being taught remotely, a number of colleges have also closed college dorms and housing, dining halls, on-campus jobs and work-study programs as well as resources such as libraries and study rooms (Smalley, 2020). This sudden and unexpected transition has in turn led to a lot of stress for students who were financially dependent on college resources and would now have to change their entire lifestyle as they would have to find other methods to support their education. In order to reduce financial stress, a number of colleges have established emergency relief funds to support students who may have experienced extreme disruptions due to this transition (Smalley, 2020). In addition, in late March the United States Congress passed the Cares Act which led to the suspension of student loan payments and a temporary $0 \%$ interest rate scheduled to last until the end of September, 2020 (Federal Student Aid. (n.d.)). Even though this Act benefits a number of students in America, international students do not gain anything from this as they are not able to take out student loans in America.

This research focuses on the financial and emotional impact of Covid-19 on international students attending PSU. The research was conducted between March 2020 and June 2020, so this study examines how international students coped with changes during the early stages of the pandemic.

\section{Data Previously Collected by Scholars}

There has been some data collected in the past that focuses strictly on the experiences of international students living in America. Firstly, a lot of researchers have focused on the stressors international students may experience during their transition. One researcher suggests that some of the socio-cultural stressors international students experience are culture shock, social isolation, financial concern, and racial discrimination, while some of the education stressors they may experience are test-taking, system adjustment and performance expectation (Chen, 1999).

When it comes to focusing on the COVID-19 pandemic and how that impacts international students, there has been fairly little research published due to how current this event is. Many experts suggest that international students may also find themselves under higher pressure with the inability to work at jobs on campus due to this pandemic. One reporter suggests that with campuses closing dorms and travel restrictions, many international students struggle to access their support system as well as find an affordable place to live (Panguluri, 2020). Another journalist also identified the fact that a number of international students are scared to go home to their family with the fear of contracting the disease (Durrani, 2020). They are also forced to live with the concern of their family's safety back home (Durrani, 2020). 
In addition to all the financial and safety stressors, there has also been an increase in reports of racism specifically towards students from East Asian countries. One article suggests that some Chinese students and graduates say they have felt increasingly uncomfortable amid rising reports of racism, with some questioning their future in the U.S. Those that have been able to return home have faced calls for them to be barred from the U.S. in case they bring back the infection with them (McCarthy, 2020). Overall, in this research I specifically look at the experiences of international students currently attending Portland State University.

\section{Method of Research}

In order to collect data for my research I chose to conduct semi-structured interviews with current international students at Portland State University. I started my research by looking for international students who are currently attending Portland State University and are willing to share their experience. Over the span of two weeks I reached out to various student-led organizations on campus that were associated with various cultural groups. I also reached out to the Office of International Affairs as they provide services to international students at Portland State University and would be able to provide deeper insight on this topic. The goal of this was to find individuals from various backgrounds as well as individuals who are not currently associated with me in order to avoid any form of bias. After I had identified four individuals that best fit my criteria, all interviews were conducted, over the span of a week, via Zoom. Overall, I interviewed two undergraduate students and two graduate students. The majors represented in this research are Computer Science, Business Administration, English and Urban Studies. The countries represented in this research are Brazil, Tanzania, India and Norway. This was done in order to ensure diversity not only in the countries represented but also in the fields of studies represented.

\section{Finding 1:Students Expressed Experiencing Extreme Financial Stress}

The average cost for an international student attending Portland State University is more than double the cost for an in-state student (Portland State University, n.d.). In addition to that, despite all the financial support offered by the U.S. government towards students during this pandemic, international and undocumented student are excluded from the roughly $\$ 6$ billion in federal aid targeted to help students to help pay for expenses like food and housing (Dickerson, 2020). Every student I interviewed during this research process expressed experiencing extreme financial stress due to this pandemic. One student mentioned, "as an international student funding is always like a stress...couple days ago I was feeling very anxious about [my] funding situation because I wasn't sure how it was going to be with the pandemic." Another student mentioned, "I 
normally try to cover all those expenses through my on-campus job but I obviously am not working any hours anymore and I am stressed $1000 \%$ because I just don't know how I am going to manage to cover all my costs like housing and food and all that other stuff." Another student stated, "I wish they offered some financial relief for international students because we pay a lot higher tuition and it is hard for anyone, of course, but also international students." The final individual I interviewed expressed being financially secure however still experiencing concerns about spending and what their financial future looks like. This individual stated, "I am still quite financially secure, but I mean it has made me more conscious about everything, like everything I spent my money on plus the currency rates are at an all-time high. I think I am a little more conservative in my spending definitely..." Overall, financial security was one of the main concerns expressed by international students.

\section{Finding 2: Students Have Expressed Anxiety with Regards to their Future}

According to data collected by Hazen and Alberts (2006), about 64\% of international students who chose to study in America made that decision with the intention of getting a job in the country right after. International students have to find a job in their field of study right after graduation in order to ensure their ability to obtain a visa to continue staying in this country. This pandemic has brought a lot of job insecurity, especially in America, which may pose a threat to international students who graduate soon and wish to reside in the country. During my interview one student mentioned, "right now, I only have an unpaid internship and like I don't know. I do see that there is realistically a very low chance of getting a job currently because of everything that is happening." Another student also mentioned, "I was planning on getting a research project this summer which this virus has made it kind of difficult to do that so ... without a research project it's kind of difficult to go for a $\mathrm{PhD}$, which was my initial plan." Overall, through this interview process, it was clear that this pandemic has created a lot of uncertainty in the future of international students which may in turn increase levels of stress and anxiety they experience.

\section{Finding 3: Students Have Expressed That They Wished They Were Better Supported by the University}

This pandemic has created great distress in the lives of more than a million international students who left their home countries to study in the United States (Dickerson, 2020). Many of these students, therefore, look to their universities for support and answers during these confusing times. Based on the data collected during the interview process, a lot of students expressed feeling a lack of support from the university during these times. One student mentioned, "I don't think they realize how much we probably need help too and there is no way to apply for 
anything because we're not a citizen." Another student expressed their frustration by saying:

I don't know, I feel like the one office who is in charge of us is doing a great job, but the university as a whole could care less about us....I don't know I call this like incompetence, like you are here to take care of all your students not just your cute American ones, and it was just so frustrating at times to like constantly remind someone to fight for you when you yourself have no idea of what's going on because you are just a student. You know you know as little as everyone else. I just remember it being so difficult.

Overall, every individual I interviewed pointed out the fact that the university, as a whole, could do a better job when it comes to supporting them.

\section{Conclusion:}

Overall, based on all the data I have collected, it is evident that international students may experience a threat to their ability to continue pursuing their education during this pandemic. This is due to all the negative impacts of this pandemic along with the government's and university's inability to successfully support them. All these factors together have resulted in an increase in financial stress as well as uncertainty with regards to the future of international students pursuing higher education in America.

During the research process it was clear that my identity as an international student influenced my data collection process. I was already familiar with the rules and regulations that specifically target international students, and this helped me ask the right questions. Finding individuals who were willing to be interviewed was fairly easy as I knew which departments on campus to reach out to. During the interview process, my identity helped generate a sense of trust as students knew that I could relate to their experience. This was evident throughout the interview process as the students being interviewed often asked me for confirmation as well as used plural pronouns such as "we" and "us" rather than "I". One example of this is when one student mentioned, on multiple occasions, "I mean you know how it is, we don't..." Overall, it is evident that throughout this research process my identity as an international student helped me access information. My identity as an international student, to a certain extent may have also negatively impacted my research especially during the interview process. In a few interviews' students did not feel the need to thoroughly explain specific experiences with the assumption that I as an international student am experiencing the same thing. This was obviously not true as our differences in nationality, class and gender makes our experiences highly unique. 
One of the limitations to this research is the fact that the international student population is very diverse. There are nearly 100 countries represented by the international student population at Portland State University. Despite the fact that this research not only covers different countries but also different continents, it may not be enough to represent all the different cultures this population may represent. My proposal for future research would be to conduct research that focuses on international students from specific countries rather than focusing on the whole population. This could help ensure that the different cultures and values will be taken into account during the interview process. Future research could also be conducted in the form of focus groups rather than individual interviews in order to encourage conversation and see what topics individuals agree to and what topics are super personalized. Overall, it is evident that international students are highly vulnerable during this time and it is therefore important to conduct further research in order to better understand their needs and identify the various steps the university may need to take in order to better support them.

\section{References}

Chen, C. P. (1999). Professional Issues: Common Stressors Among International College Students: Research and Counseling Implications. Journal of College Counseling, 2(1), 49-65. doi:10.1002/j.2161-1882.1999.tb00142.x

Dickerson, C. (2020, April 25). 'My World Is Shattering': Foreign Students Stranded by Coronavirus. New York Times. Retrieved August 01, 2020, from https://www.nytimes.com/2020/04/25/us/coronavirus-internationalforeign-students-universities.html

Durrani, A. (2020, March 13). How U.S. Coronavirus Measures Affect International Students. U.S. News Retrieved August 04, 2020, from https://www.usnews.com/education/best-colleges/articles/how-uscoronavirus-measures-affect-international-students

Federal Student Aid. (n.d.). Coronavirus and Forbearance Info for Students, Borrowers, and Parents. Student AidRetrieved August 03, 2020, from https://studentaid.gov/announcements-events/coronavirus

Galstyan Law. (n.d.). F-1 Student Visa Privileges and Limitations. Retrieved August 04, 2020, from http://www.galstyanlaw.com/visas/students/f-1privileges-and-limitations/

Hazen, H. D., \& Alberts, H. C. (2006). Visitors or immigrants? International students in the United States. Population, Space and Place, 12(3), 201216. doi: $10.1002 / \mathrm{psp} .409$

McCarthy, S. (2020, April 14). Chinese students battle rising tide of prejudice in U.S. South China Morning PostRetrieved August 04, 2020, from 
https://www.scmp.com/news/china/article/3079877/coronavirus-meanschinese-students-battle-rising-tide-prejudice-us-fear

Panguluri, N. (2020, April 14). Commentary: International students hit hard by virus. Moscow Pullman Daily News Retrieved August 04, 2020, from https://dnews.com/coronavirus/commentary-international-students-hithard-by-virus/article e4650da3-23a5-52d3-80d4-9dd909f754d9.html

Portland State University (n.d.). Portland State Office of International Affairs: International Student Services Welcome. Retrieved August 01, 2020, from https://www.pdx.edu/international-students/

Portland State University (n.d.). Undergraduate Tuition \& Fees. Retrieved August 04, 2020, from https://www.pdx.edu/student-finance/tuition/undergraduate

Reuters. (2020, July 20). What 1.1 million foreign students contribute to the U.S. economy? The Hindu Retrieved August 01, 2020, from https://www.thehindu.com/news/international/what-11-million-foreignstudents-contribute-to-the-us-economy/article32028619.ece

Smalley, A. (2020, July 27). Higher Education Responses to Coronavirus (COVID-19). National Conference of State Legislatures. Retrieved August 01, 2020, from https://www.ncsl.org/research/education/highereducation-responses-to-coronavirus-covid-19.aspx

U.S. Citizenship and Immigration Services. (2020, May 01). Students and Employment. Retrieved August 01, 2020, from

https://www.uscis.gov/working-in-the-united-states/students-andexchange-visitors/students-and-employment 